Ankara Üniversitesi Türk İnkılâp Tarihi Enstitüsü Atatürk Yolu Dergisi

S 39, Mayls 2007, s. 497-502

\title{
29 Ekim 2023'e Mektup
}

\section{Züleyha ÇUBUK ${ }^{*}$}

(Tarih 29 Ekim 2006. vakit sabahtır. Züleyha tek başına yatağında oturmuş televizyona göz atmaktadır. Durur. Uzunca bir sessizlik. Hiç konuşmaz, ancak meraklı bakışlarla bir şeyleri dinliyor gibidir. Aslında kendi iç sesini dinlemektedir.)

İç ses: (bunalmış)of!... İyi misin sen? Hayalet görmüş gibisin. Dilini mi yuttun? (Züleyha cevap vermez, iç ses sıkılır) Bunalıyorum. (bağırır) Yeter artık! Hareket et biraz, kalk ayağa!

Züleyha: (dalgın) Evet... Bir hayalet gördüm, mektup yazmamı söyledi. (kararsız) Yazmalı mıyım? (kendi kendine) İç sesimi dinlememi ve onları kağıda geçirmemi istedi. Söz uçar yazı baki kalırmış. Mektubu nereye göndereceğimi bilmiyorum, adres vermedi. (ne yapacağını bilemez) Yazmalı miyım?

İç ses: (umutlantr) Otur ve yaz mektubunu!

(Yată̆ından kalkar. Masasına oturur ve bir mektup yazar.)

\section{"Sevgili Cumhuriyet,}

Bugün 29 Ekim 2006. hayatımıza girişinin seksen üçüncü yıl dönümündeyiz. Öyle zor şartlarda geldin ve öyle çok şeyi deģiştirdin ki bizde! Hayatımızın değişilmez bir parçası olmaya devam ettiğ in sürece birçok şeyi daha değiştirmeye devam edeceksin.

$\mathrm{Bu}$ sabah uyanıp sana mektup yazmaya karar verirken, içinde bulunduğum ruh durumum; "Bu sabahın önemi nedir sence? Niye hala yataktasın? Niye konuşmuyorsun? Sıkıldın sorularımdan galiba. Peki sen bana sor öyleyse: Mesela neden bugün mutsuzsun(?) de. Az önce televizyon kanallarına göz atarken iyiydin. Şimdi neden kendini sıkıyorsun ey Züleyha'nın içindeki ruh durumu (!) de." Diye başımın etini yerken; dediği gibi bir hayalet gördüğümü ve onun bana bir mektup yazmam gerektiğini

· Dil ve Tarih-Coğrafya Fakültesi, Tiyatro Bölümü Tiyatro Tarihi ve Teorisi Ana Bilim Dalı, Sınıf Öğrencisi 
söylediğini bilseydi _belki de biliyor_bana mutlaka deli derdi. Ama hayır, ben deli değilim. Sadece kendi kușağımın düsünme kelimesinden nefret ettiği kadar çok seviyorum bu kelimeyi. Hiç olmayacak yerde değil, seksen üçüncü yaşını doldurduğun günün sabahında artık sadece düşünmek için de değil; bu kez hem düşünüp hem de onları kağıda dökmek ve on yedi yıl sonra bu yazdıklarımı okuduğunda nelerin değişip nelerin değişmediğini sana gösterme fikri doğdu aklıma. Ya da bunalan ruh durumuma...

Her yaş gününde devlet ileri gelenlerimiz, önce seni bizim hayatımıza sokan biricik devlet adamımız Atatürk'ün anıt kabrini ziyaret edip saygı duruşunda bulunup; ardından anı defterini imzalarlar. Daha sonra meydanların ya da stadyumların kendileri için hazırlanmış protokol localarına otururlar. Öncesinde, yoklama zoruyla öğretmenleri tarafından söz konusu mekanlara getirilen öğrenciler, saatlerce ayakta bekletilmek pahasına yağmura, çamura, sıcağa, soğuğa rağmen; özellikle protokol localarının önüne kalabalık görüntüsü oluşturmak maksadıyla ayağa dikilmişlerdir. İstiklal Marşı okunur, sonrasında bazı devlet ileri gelenlerimiz günün anlam ve önemini belirten, saatler sürecek bir metin okurlar. Bu arada bazı öğrencilerin eline bayraklar verilerek, alkış ve tezahürat yapmaları istenir. Zorunlulukların bitiminde protokol locası için özel gösteriler armonisi gerçekleştirilerek, devlet ileri gelenlerimizin canlarının sıkıntısı giderilir. Her sene hiç sapmadan bu silsile mekanik bir düzende tekrarlanır. Bu silsile diyorum; çünkü yapay bir coşkuya mahkum edildik. Sana, o ilk yıllarında duyulan coşkudan eser kalmadı. Yeni kuşakların, önemini kavramayı bilmiyor daha, kaldı ki coşkunu hissetsinler bedenlerindeki her hücrede. İşte bu yüzden yataktayım ve hüznüm taşma eğilimi gösterdi bu sabah. Çünkü bize her geliş yıldönümünü televizyonlardan takip etmeye ve yapay bir coşkuyla donatılmaya mahkum edildik. Tek sebep sanma! Hayır! Bu sadece bir nedeni... Bir insan ömrü kadar yaşın var şimdi. Bu ülkede nice insan darbeler ve muhtıralar yaşadı. Ama en acı "12 Eylül"ü unutmak ve etkilerini silmek asla mümkün olmadı. Biliyorum bu dönemlerde ağır hastalıklar geçirdin. Soluğun ara ara kesintiye uğratıldı, sarsılmak istendin. Yine de hala ayaktasın. 100'ünü devirip bir çınar olduğunda da ayakta olmayı sürdüreceksin. Sen bu satırları okurken de ben 34 'ümde olacağım ve sen sevgili cumhuriyet hayatımızda olmaya devam edeceksin.

Bir cumhuriyet çocuğuyum, seninim. Bir üniversiteliyim, mutluyum. Seninle birlikte varlığına bașlayan Türkiye'nin kurulan ilk fakültesinde okuyorum. Bir devletin cumhuriyetine verilecek en güzel armağanın, o devletin gençlerinin eğitimi olduğunu biliyorum. Eğitimimizin görmezden gelinemez gerçekleriyle giderek büyüyen sorunları olduğunu da biliyorum, görüyorum; çünkü bu sorunlarla birlikte yaşıyorum. Acı olan; sorunların var olması değil, bunların yıllardır nihai bir çözüme kavuşturulamaması. Öğrencilerin, onlarla birlikte sıkıntı çeken ailelerinin; sadece onların değil kürsülerde ders veren öğretim görevlilerinin ve ailelerinin, üniversite personelinin ve onların da ailelerinin aynı dertten muzdarip olduklarını; kısacası eğitimin bütün kadrolarına buram buram yansıyan en temel sorunun, 
ekonomik çıkmaz olduğunu kimse mi göremedi ve görmek istememekte diretiyor hala? Oysa seni sağlıklı bir şekilde yaşatabilmek için sana özgü, bir dehanın ürünü ilke ve inkılaplarımız var ve hangi zaman dilimi içerisinde tam anlamıyla hayata geçirildi bilmiyorum. Sanal etkinliklerle senin de ve bizim de can damarımız ekonomimiz bir pamuk ipliğine bağlı şimdi, ki dış müdahalelere karşı zırhlarımız bir bir yere insin. Gerçek bu! Çözümün üretim ekonomisi olduğunu görememek ya da görmezden gelmek, bir ülkenin geleceğiyle oynamak _ki bir ülkenin geleceği o ülkenin gençleridir ${ }^{1}$ demek. Acı olan, bir türlü iyileştirilemeyen ekonominin, bilim yuvalarında çırpınan öğrenci ve öğretim kadrolarıyla personeline yansımalarının "geçim sıkıntısı" olduğu gerçeğiyle karşı karşıya olmamız. Bir akademisyenin öğrencisiyle; bir bilim adamı ve eğitimci olarak üst seviyede bir başarı ilişkisi kurabilmesi için, zihnini ilk sırada meşgul eden "geçim sıkıntısı" sorununu atlatabilmesi gerekir ve vak'a bilinir ki çözüme yardımcı olacak başlica etken de ekonomik iyileşme. Sana verilecek en güzel armağan bizlerin eğitimi ise, eğitimin en önemli sorunu olan ekonomik sıkıntı da var olan gerçeğin çözülmesi gereken ilk sorunu(!) değil mi?

Gençleri az çok tahmin edersin; bu yaşlarda pembe gözlük takıp olmayacak hayallere kapılanlarımız da vardır, kendisini kara bir dünyada görenimiz de... Ama hepimiz ekonomik sorunların zincirleme bir reaksiyonla diğer sorunları doğurduğunu biliriz. Mesela; neden üniversiteler lise mezunlarının sadece \%25'ini alabiliyor? Neden liselerde yanlıs alan seçimiyle göz göre göre öğrenciler üniversitelerde mutsuz oldukları alanlarda okumak zorunda bırakılıyor? Evet bizler üniversitelerde eğitim(!) görüyoruz da, bu sınıflar niye kalabalık ve çok sıcak ya da çok soğuk ve birbirimizin konuştuğunu anlayamayacağımız kadar kötü bir ses düzenine sahip ve her zaman toz toprak içinde ve sözde temiz?... Niye üniversitelerimizin kütüphanelerine ulaşmak için öğrenci işlerimize ek kaynaklar sunmak zorunda kalıyoruz? Böyle mi geçim sıkıntısından kurtulacağız? Hadi bu kaynakları biz öğrenciler sunduk(!) diyelim, niye kütüphanelerimize ulaştığımızda hayal kırıklığına uğruyoruz? Bu ülkede neden üniversite kütüphanesi deyince akla sadece Bilkent geliyor? Bilkent de olmasa üniversitelerimiz ne yapar acaba, da yetmiş milyonluk bir ülkenin üniversite kütüphanelerinden bahsederken zihinlerden sadece 1 isim geçmesini, var sen düşün!

$\mathrm{Bu}$ değil bir elbet; alanımızla ilgili olmayan ancak girmek zorunda bırakıldığımız derslere zaman varken; sosyal ve kültürel faaliyetlere katılabilecek zamanımız yok! Ama yoğun eğitim-öğretim yılının ceremesini üzerimizden atabilmemiz için; sonradan faiziyle fazla fazla almak koşuluyla kredi ve yurtlar kurumunun yatırdığı harçları, astronomik rakamlarla konser vermeyi kabul eden arabesk-fantezi-pop-rock şarkıcılara akıtarak, zihin yorgunluğunun iki saatlik konserlerle atılabileceği fikri yaşıyor üniversitelerimizde. Zamanında yatmayan okul burslarına bel bağlayan

\footnotetext{
${ }^{1} \mathrm{~K}$. Atatürk.
} 
öğrencinin ailesinden harçlık isteyemeyecek durumda olduklarını bilerek bir tas çorbaya talim etmesi, böylece düzenli beslenememesi ile yorgun bedeninin sağlık sorunlarına direnememesi ve üzerine de psikolojik sorunlarının eklenmesini_konser meselelerinden bahsedilmişken_saymak da yerinde olur.

Biliyorum mektup tatsız gidiyor, fakat gerçeklerin acı ama dile getirilmesi gerektiği de muhakkak. Şu da bir gerçek; ülkemiz ortaöğretimde genel ve mesleki eğitim yapılmaksızın üniversitelere öğrenci hazırlanmakta, üniversiteyi bitiren herkes devletten iş beklemekte. Fakat hayattan kopuk eğitim veren üniversitelerimiz piyasanın gereksindiği donanımda elemanlar yetiştirememekte, üniversite mezunlarına istihdam olanakları sağlanamamakta. Göstermelik stajlarla eğitim-öğretimin en önemli aşamalarından biri olan "pratik eğitimle deneyim kazandırma" eylemi savsaklanmakta. Ama sorun aslında en başta; başarılı olması hedeflenen bir eğitim-öğretimin yolu, başta öğreteni yetiştirmek. İstisnalar dışında-süslü cümleciklerle buram buram kalite kokan bir hoca olduğunu göstermeye çalışan bir eğitmen zihniyeti ya da akademisyenlik gibi üstün vasıf gerektiren konumda olan kişinin akademisyenliği bir ticaret kapısı olarak görüp zenginlik ve etiket hayalleri kurması durumuyla karşı karşıyayız. Maalesef üniversitelerimizde de kalite sorunları var. Maalesef akademisyen sayımız da yetersiz, üniversite sayımız da. Maalesef akademisyenlerimizin omuzlarına kaldıramayacakları kadar çok yük yüklenmekte; bu durumda da bilgi üretme ve bunu yayma sorunlarını ortaya çıkarmakta, araştırmalar desteklenmemekte ve bilginin dolaşımı sağlanamamakta. Maalesef yabancı dil ile ilgili sorunlar da çözülememekte.

Bizi bize veren cumhuriyetsin sen! Bizim sigortamızsın! Sağlamlığın verecek gücü bize! Engelleri bir bir aşacağız! Sorunları seninle çözüme kavuşturacağız! Sen var olduğun sürece biz de var olacağız! Bir yerlerde bir sorun varsa orda mutlaka bir çözüm de saklı değil midir? Küçük bir cinin gökkuşağının altına bir altın küpü koyduğu gibi... Tarih; neyin ne olduğunun hesabını yapmadan bir ideolojiyi savunarak kendi trajedisini yazmış nice gençlik öyküleriyle dolu. Niceleri ise, haklı olduğu bir konuda ve üniversite arkadaşlarının derste olduğu saatlerde, onların bilerek veya bilmeyerek derslerini sabote edip kendi elleriyle kendilerini haksız duruma düşürdüğü bir konumda. Niceleri de farklı görüşlerde oldukları için birbirlerini nedensiz bir öfkeyle doğrama gayretinde... Bir eğitim sistemi öğrencisine; güvensizlik, öfke, kin, nefret, bilgi yerine bilgisizlik, baştan kaybetmişlik, mutsuzluk, yalnızlık duygularını veremez, vermemeli... Vermeyecek öyle değil mi?

Bugün 29 Ekim 2006. Seksen üçüncü yaş gününü kutladığımız günün sabahındayım. Yağmurun, toprağı bereket tohumlarıyla dövdüğü anı yaşıyorum. Hangi şehirde ve nerede olduğum önemsiz. Ruh durumum, onu bunalttı̆̆ım için bana bir takım sorular sordu. Böylece o da beni bunalttı ve ödeşmiş olduk. Kendisine itiraf edemediğim şeyleri de sana yazıyorum 
şimdi. Dile getirdiğim sorunların_eğer bir yerde sorun varsa orada çözümü de olduğu gerçeğini göz önünde bulundurarak_ kendine has çözümleri olduğunu da izah etmek istiyorum: Eğitimimizin ekonomik sorunlarının aşılması, akademisyenlerimizin ve biz öğrencilerin bu anlamda iyileştirilmesinin, çözümün ilk adımı olduğu sence de aşikar değil mi? Sen de üniversitelerimizde bir dil sorunu olduğunu ve Türkçe'nin hak ettiği bilim dili sıfatının teslim edilmesi; "Sezar'ın hakkının Sezar'a verilmesi" gerektiğini düşünmüyor musun? Sence de şunu karıştırmıyor muyuz: En az bir veya iki yabancı dil bilmeliyiz. Ancak daha ilkokuldan başlayıp, yüksek öğretimde de bunun devamını sağladığımız yabancı dilde eğitime son vermeliyiz. Ayrıca yetmiș milyonluk bir ülkeye bu kadarcık üniversite az değil mi? Niye daha fazlasını açamayalım? Donanımlı akademisyenlerle dört dörtlük kadrolar kurabilmek ve bu akademisyenlerimizin o süslü cümleciklerle etiketli görünme gereği duymamaları, sadece profesörlüğe yükselmek için profesör olmaya çalıșmamaları koşuluyla... Üniversitelerimizin müfredatlarını ülke ihtiyaçlarına ve çağın koșullarına göre düzenlemek; bu düzenleme işini de akademisyen, öğrenci, veli ve iş kaynaklarıyla birliktelikli yürütmek de zor olmasa gerek! Gereksiz bölümlerin ve öğrenci sayılarının iyi niyetli zihniyetlerle gerekli koşullara göre düzenlenmesi gerekmez mi ki üniversiteler sadece diploma veren kuruluşlar olmaktan çıksın!

Yüzlerce yıllık saltanatın küllerinden, sancılı ve Sarıkamış'larda, Yemen'lerde, Gelibolu'larda, Sakarya'larda ve Anadolu'nun her karışında şehitlerinin parçalanmış bedenlerinden akan kanlarla doğdun; ama özgür ve boyunduruksuz, dayatmasız, manda ve himayesiz... Kimsenin "demokrasi getireceğiz" çabasıyla değil, halkının işgale uyanışıyla, önderinin dehasıyla, renkli mozayiğinin tek bir millet olma coşkusuyla, Kuvayi Milliye ruhuyla doğdun! Laikliği ve demokrasiyi doğurdun! Seni dinsizlikle suçladılar; ama sen dinini kendine saklamayıp halkına verdiğin gerçeğini göremeyen yobazlara kulak asmadın. Şehidin Kubilay'a ağladın.; ama gözlerini kapamadın. Zaman zaman birilerinin nefesini kesme gayretlerini gördün. Ama güçlüsün; izin vermedin, vermeyeceksin. Çünkü biz seniniz, sana armağanız, ülkemize gelecek, sana neferiz. Biz senin olmalıyız. İşte bu yüzden; "Eğitim ve öğretimde uygulanacak yöntem; bilgiyi insan için fazla bir süs ya da uygar bir zevkten çok, maddi hayatta başarılı olmayı săglayan uygulanabilir ve kullanılabilir bir araç haline getirmektir." ${ }^{2}$ işte bu yüzden; "Okullar; genç beyinlere, insanlığa hizmeti, millet ve memlekete sevgiyi, bağımsızlığı öğretirler." ${ }^{\text {3 }}$ Ve işte bu yüzden Türkiye ve Türk üniversiteleri bu gerçeklerine çözüm üretmeli; bir an önce de uygulamaya koymalıdır.

Yüzüncü yaş gününde mektubumu okurken, nelerin değişip nelerin değişmediğini görmen ve aslında kendi eksiklerimizin neler olduğunu dile getirerek; sana hazır olarak yetişebilmemiz için yazdım bu mektubu. Şunun

\footnotetext{
${ }^{2} \mathrm{~K}$. Atatürk.

${ }^{3} \mathrm{~K}$. Atatürk.
} 
şurasında yüzüncü yaşına pek bir şey kalmadı; ama daha var. Sana yetişebiliriz; yetişmeliyiz ki bizi sar, sana sevgimizi al. Çünkü biz sensiz olamayız.

Yüzüncü yaşına kadar sana hazır olabilmek dileğiyle... Sana gelene kadar ve geldikten sonra da... Sevgiler...

ZÜLEYHA"

(Züleyha mektubunu tamamlar. Duygu ve düşüncelerini dile getirmiş olmanın verdiği huzuru tatmaktadır. Eylemsizliğini, mektup yazarak eyleme dönüştürmüş; bu durumda ruh durumu da sessizliğe gömülmüştür. Şimdi onun kafasında şu iki şey vardır: Düşüncelerine yanlış değer biçileceği ve anlaşılamama olasıllı̆̆. Ancak, bunları zamanın göstereceği gerçeğini göz önünde bulundurarak; yağan yağmurun ardından açan gökyüzünün tadını çıkarmaya karar verir. Odasının penceresini aralar. Kasvetli odası, odasına dolan ışıkla aydınlanır.)

Perde iner... 